\title{
First record of Gorgona guitarfish, Rhinobatos prahli, from the Gulf of Tehuantepec, Mexican Pacific
}

\author{
MARIBEL CARRERA-FERNÁNDEZ, FELIPE GALVÁN-MAGAÑA AND OFELIA ESCOBAR-SÁNCHEZ \\ Departamento de Pesquerías y Biología Marina, Centro Interdisciplinario de Ciencias Marinas, Avenida Instituto Politécnico \\ Nacional s/n, Playa Palo Santa Rita, Apartado Postal 592, La Paz Baja California Sur, 23000 México
}

The capture of two Gorgona guitarfish, Rhinobatos prahli, in the Gulf of Tehuantepec represents the first record for the species in Mexican waters and its northernmost range extension in the eastern Pacific.

Keywords: Rhinobatos, guitarfish, Mexican waters, distribution, Gulf of Tehuantepec

Submitted 22 October 2011; accepted 10 November 2011

\section{INTRDDUCTION}

Little information exists on the biology, ecology and geographical distribution of the Gorgona guitarfish, Rhinobatos prahli Acero \& Franke, 1995. It has been recorded from few localities from north-western Costa Rica to northern Peru, but scarce data makes it difficult to establish whether its occurrence is continuous across this range. The poor information available on this species led to an assessment of 'Data Deficient' by the International Union for Conservation of Nature (IUCN, 2011), thus it is necessary to better document its distribution and abundance (Kyne, 2007). In this context the present report expands the distribution of the Gorgona guitarfish northwards to the Gulf of Tehuantepec in southern Mexico (Figure 1).

The Gorgona guitarfish belongs to the group of batoid elasmobranchs called 'guitarras' by Mexican fishermen. It is characterized by a brown upper surface, including both dorsal fins and the caudal fin, and with more-or-less regularly dispersed small white spots (sometimes ringed with darkbrown); a pale area on each side of the rostral cartilages; a yellow border on the lower half of the caudal fin; a pale underside (ventrum); underside of the snout with black blotches at its tip and sides; with edges of disc in light-brown; a tail with approximately 20 light-brown blotches (Figure 2); approximately 70-80 small denticles from the nape to the origin of the first dorsal fin; several small denticles on each shoulder (Acero \& Franke, 1995; Compagno, 1999; Robertson \& Allen, 2008).

\section{MATERIALS AND METHDDS}

During September 2005, two individuals of Rhinobatos prahli were observed (one photographed) at the Chipehua fishing

Corresponding author:

F. Galván-Magaña

Email: galvan.felipe@gmail.com camp $\left(16^{\circ} 02^{\prime} 3^{\prime \prime} \mathrm{N} 95^{\circ} 22^{\prime} 6^{\prime \prime} \mathrm{W}\right)$, in the western Gulf of Tehuantepec where there is an area characterized by a wide continental shelf. Chipehua Bay has a range along the coast of approximately $8 \mathrm{~km}$; its coast is rocky and steep, while the bottom offshore is rocky and sandy, with depths varying from 4 to $36 \mathrm{~m}$ (Gentier, 1982). Specimens were captured by monofilament gill-nets deployed in the small-scale fishery operating from this camp. Other, more abundant guitarfish such as R. glaucostigma were also landed in the fishery. The individuals were identified using keys by Jiménez-Prado \& Béarez (2004) and Robertson \& Allen (2008). Total length was measured and sex was determined for both, but state of maturity could only be determined for the male. The two individuals were not preserved.

RESULTS

The two individuals differed from other species of Rhinobatos recorded from the area by presenting a brown colouring dorsally, with approximately 100 white spots (many ringed in dark-brown) more-or-less regularly dispersed over its surface.

An annotated list of published records of this species in the eastern Pacific is shown in Table 1. The female reported here measured $77 \mathrm{~cm}$ total length (TL), but it was not possible to determine maturity. The male measured $71 \mathrm{~cm} \mathrm{TL}$, the clasper measured $10 \mathrm{~cm}$ long and presented adult characteristics such as rotation, open rhipidion and calcification. Unfortunately, preservation and disposition in a scientific collection of both individuals was not possible, because the fishermen sold their entire catch, and only the female was photographed (Figure 2).

\section{DISCUSSIDN}

The individuals reported here were within the size range reported for the species from the coast of Colombia in the eastern Pacific (50-90 cm TL) (Payan et al., 2010), which 


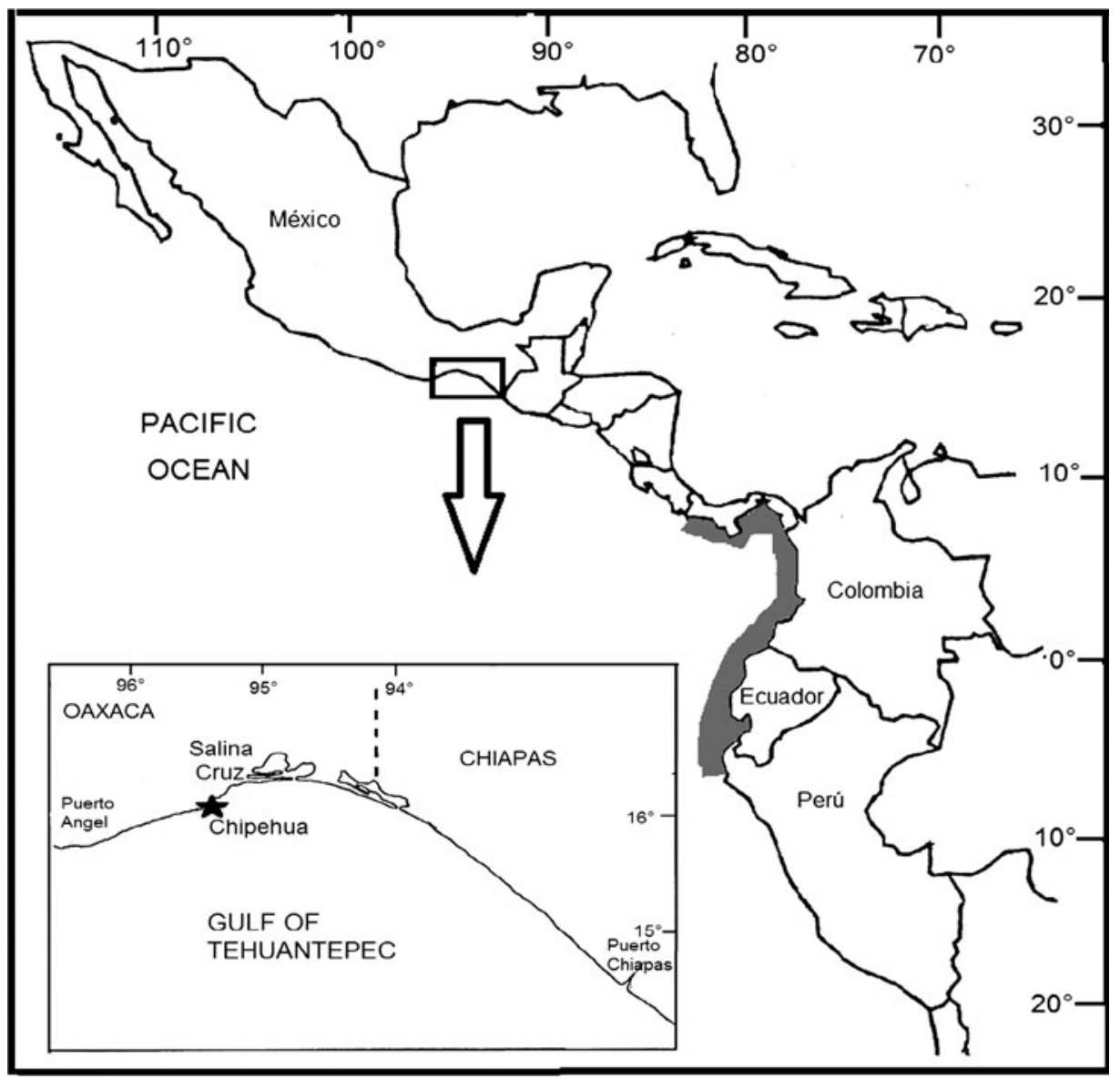

Fig. 1. Capture site of Rhinobatos prahli in the Gulf of Tehuantepec; grey area represents the former known distribution.

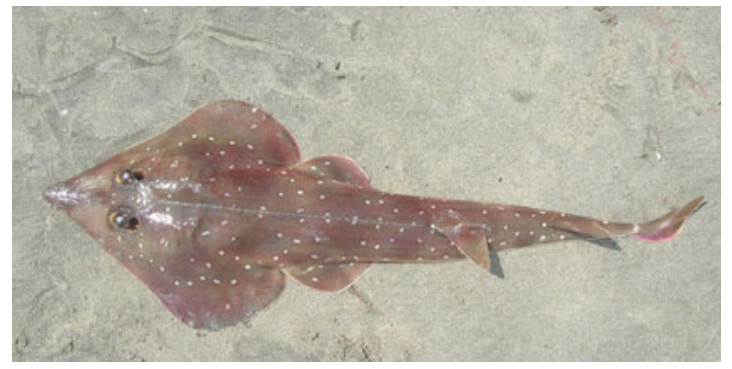

Fig. 2. Dorsal view of the female Gorgona guitarfish Rhinobatos prahli from Chipehua Bay, Gulf of Tehuantepec, Mexico. were estimated from underwater photographs of specimens in natural habitat, and elsewhere in the tropical eastern Pacific (Table 1). Fishermen in the Gulf of Tehuantepec group all species of guitarfish common in the area (e.g. Rhinobatos leucorhynchus and R. glaucostigma) which represented $48 \%$ of all rays captured. These observations are obtained from the sampling of sharks and rays between September 2004 and August 2006, in which the specimens of Gorgona guitarfish described here were observed, and the fishermen said that this species is uncommon in the area, so it is possible that the frequency of occurrence of $R$. prahli may be low, with only occasional captures.

Table 1. Annotated summary of Gorgona guitarfish records from the eastern Pacific.

\begin{tabular}{llllll}
\hline Year & Location & Total length cm & Sex & State of maturity & Literature cited \\
\hline 1995 & Colombia (Isla de Gorgona) & 81 & Male & Adult & Acero \& Franke, 1995* \\
1999 & Ecuador (Santa Rosa and Puerto López) & $60-75$ & Unknown & Unknown & Jiménez-Prado \& Béarez, 2004 \\
1999 & Northern Perú (Puerto Pizarro, Tumbes) & 71 & Male & Adult & Béarez, 2000 \\
1999 & Costa Rica, Panamá (Golfo de Chiriquí) & Unknown & Unknown & Unknown & Robertson \& Allen, 2008 \\
2005 & Ecuador (Puerto López) & 78.2 & Male & Adult & Béarez, personal communication, 2011 \\
2005 & Gulf of Tehuantepec & 71 & Male & Adult & Present study \\
2005 & Gulf of Tehuantepec & 77 & Female & Unknown & Present study \\
2006 & Colombia (Amargal) & Unknown & Unknown & Unknown & Payan et al., 2010** \\
2007 & Colombia (Pizarro, Chocó) & 58.5 & Female & Unknown & Payan et al., 2010 \\
2008 & Ecuador (Puerto López) & 76.5 & Female & Adult & Béarez, personal communication, 2011 \\
2009 & Colombia (La Parguera) & $50-90$ & Unknown & Unknown & Payan et al., 2010** \\
\hline
\end{tabular}

*, holotype; **, observations of living individuals in their natural habitat. 
The fishing area investigated in the Gulf of Tehuantepec shows characteristics similar to those reported by Payan et al. (2010), whose photographs showed living individuals of $R$. prahli in sandy and rocky environments near coral reefs at 18-24 m depth off the Colombian coast. In contrast, the holotype described from Gorgona (Island) National Natural Park, Colombia, was caught in deeper water at $70 \mathrm{~m}$ depth (Acero \& Franke, 1995).

Heretofore, $R$. prahli had not been recorded in Mexican waters (Castro-Aguirre \& Espinoza-Pérez, 1996) and the two individuals reported here (with voucher as the photograph of the female, Figure 1) represent the first as well as the northern-most record.

\section{ACKNDWLEDGEMENTS}

We thank the fishermen of Chipehua Bay for allowing us to take photographs of the guitarfish. We thank Secretaria de Agricultura, Ganadería, Desarrollo Rural, Pesca y Alimentación (SAGARPA); and Consejo Nacional de Ciencia y Tecnología (CONACYT) for their support in the project 2003-CO1-101-/A-1 'Caracterización de la pesquería artesanal de los tiburones desembarcados en Salina Cruz, Oaxaca, México'. M.C.F. and O.E.S. thank CONACYT and the Instituto Politécnico Nacional (IPN) for financial support. F.G.M. thanks Estímulo al Desempeño de los Investigadores (EDI) and Comisión de Operación y Fomento de Actividades Académicas (COFFA) del IPN for fellowships.

\section{REFERENCES}

Acero A.P. and Franke R. (1995) Nuevos registros de peces cartilaginosos del Parque Nacional Natural Gorgona (Pacífico Colombiano). II. Rayas y descripción de una nueva especie. In La Isla de Gorgona, Nuevos estudios Biológicos. Biblioteca José Jerónimo Triana, Instituto de Ciencias Naturales, Museo de Historia Natural, Universidad Nacional de Bogotá 11, 19-21.

Béarez P. (2000) Primer registro de Rhinobatos prahli (Chondrichthyes: Rhinobatidae) en el Perú y apunte sobre un espécimen grande de Pontinus clemensi (Osteichthyes: Scorpaenidae). Wiñay Yachay (Lima), Perú 4, 61-64.
Castro-Aguirre J.L. and Espinosa-Pérez H. (1996) Listados faunísticos de México. VII. Catálogo sistemático de las rayas y especies afines de México (Chondrichthyes: Elasmobranchii: Rajiformes: Batoideiomorpha). México, D.F.: Instituto de Biología, Universidad Nacional Autónoma de México.

Compagno L.J.V. (1999) Checklist of living elasmobranchs. In Hamlett W.C. (ed.) Sharks, skates, and rays: the biology of elasmobranch fishes. Baltimore, MD: Johns Hopkins University Press, pp. 471-498.

Gentier M.C. (1982) Contribución al estudio las pesquerías marítimas con base en el puerto de Salina Cruz, Oaxaca. Tesis de licenciatura. Facultad de Ciencias, Universidad Nacional Autónoma de México, México, D.F.

IUCN (2011) IUCN Red List of Threatened Species. Version 2011.1. http:// www.iucnredlist.org (accessed 21 October 2011).

Jiménez-Prado P. and Béarez P. (2004) Marine fishes of continental Ecuador. Sociedad para la Investigación y Monitoreo de la Biodiversidad Ecuatoriana/Instituto Nazca de Investigaciones Marinas/ Instituto Francés de Estudios Andinos. Quito. Tomo II, 393 pp.

Kyne P.M. (2007) Rhinobatos prahli. In IUCN, 2010: IUCN Red List of Threatened Species. Version 2010.4. http://iucnredlist.org (accessed 18 May 2011).

Payan L.F., Mejía-Falla P.A., Navia A.F. and Lozano R.A. (2010) New records of Gorgona guitarfish Rhinobatos prahli on the Colombian Pacific coast. Marine Biodiversity Records 3, e52. doi:10.1017/ S1755267210000114.

and

Robertson D.R. and Allen G. (2008) Peces costeros del Pacífico Oriental Tropical: un sistema de información en línea. Version 1.o. Balboa, Panamá: Smithsonian Tropical Research Institute. http://www.stri. $\mathrm{org} / \mathrm{sftep}$ (accessed 20 May 2011).

\section{Correspondence should be addressed to:}

F. Galván-Magaña

Departamento de Pesquerías y Biología Marina Centro Interdisciplinario de Ciencias Marinas

Av. Instituto Politécnico Nacional s/n Playa Palo Santa Rita, Apdo. Postal 592 La Paz Baja California Sur

México, 23000

email: galvan.felipe@gmail.com 